\title{
THE STABILIZATION OF NANO SILVER ON POLYESTER FILAMENT FOR A MACHINE-MADE CARPET
}

\author{
STABILIZACIJA NANODELCEV SREBRA NA POLIESTRSKEM \\ VLAKNU ZA STROJNO IZDELAVO PREPROG
}

\author{
Khashayar Mohajer Shojaei, Ali Farrahi, Hossein Farrahi, Ahmad Farrahi \\ Farrokh Sepehr Kashan Company (Farrahi Carpet), Kashan, Iran \\ Khashayar045@yahoo.com \\ Prejem rokopisa - received: 2014-07-20; sprejem za objavo - accepted for publication: 2014-09-02
}

doi:10.17222/mit.2014.113

\begin{abstract}
Nowadays, polyester filament yarns with permanent anti-bacterial characteristics are known as an innovative yarn in the textile industry for machine-made carpets and garments. Different methods, such as chemical modification, entrapment and encapsulation, have been applied to stabilize the silver nanoparticles on polyester filament yarn for use in machine-made carpets. In this article we modified the nano-silver particles by a chemical reaction in order to produce a polyester filament yarn with permanent anti-bacterial characteristics using a spraying method. The anti-bacterial tests were carried out on the nano-silver-coated machine-made carpet according to ATCC 27853, 25923 and 25922 some $72 \mathrm{~h}$ before and after the washing process. The results showed that the nano-silver-coated polyester machine-made carpet has a permanent anti-bacterial characteristic.

Keywords: anti bacterial characteristic, polyester filament yarn, machine-made carpet, DLS method, washing processes, bacteria, surfactant, Mac Farlen

Dandanes je preja iz poliestrskih vlaken s trajno protibakterijsko odpornostjo poznana kot inovativna preja $\mathrm{v}$ tekstilni industriji za strojno izdelavo preprog in oblačil. Različne metode, kot so kemijska obdelava, ujetje in enkapsulacija, so bile uporabljene za stabilizacijo nanodelcev srebra na vlaknih poliestrske preje za strojno izdelavo preprog. Članek predstavlja modifikacijo nanodelcev srebra s kemijsko reakcijo z naprševanjem za izdelavo vlakna poliestrske preje s stalno protibakterijsko odpornostjo. Protibakterijski preizkusi so bili opravljeni na strojno izdelani preprogi, prekriti z nanodelci, skladno z ATCC 27853 , 25923 in 25922, $72 \mathrm{~h}$ pred pranjem in po njem. Rezultati so pokazali, da ima strojno izdelana preproga iz poliestra, prekritega $\mathrm{z}$ nanodelci srebra, trajno protibakterijsko odpornost.

Ključne besede: protibakterijske lastnosti, preja iz poliestrskih vlaken, strojno izdelana preproga, DLS-metoda, postopek pranja, bakterija, površinska aktivnost, Mac Farlen
\end{abstract}

\section{INTRODUCTION}

Microbial organisms, bacteria and micro-organisms are the main reasons for sickness, infections and bad odours, etc. In fact, increasing death rates in many underdeveloped countries, such as many African countries, led to the legislation of global and social policies in order to overcome this challenge. Such problems and needs have led to a resurgence in the use of silver- and copper-based antiseptics that may be linked to broadspectrum activity and a far lower propensity to induce microbial resistance than antibiotics ${ }^{1}$.

The anti-bacterial characteristics of silver and silver salts have been observed since antiquity ${ }^{2}$. Silver is currently used to control bacterial growth in a variety of applications, including dental work, catheters and burn wounds ${ }^{3,4}$

In fact, it is well known that Ag ions, Ag-based compounds, copper and brass compounds have a strong biotical effect on many bacteria species, such as E. coli, $P$. aeruginosa and $S$. aureus ${ }^{5}$.

A lot of information is available about the practical use of nanoparticles for food safety and hygiene, the disinfection of water in swimming pools and hospitals, wound healing, air disinfection and surface sanitation ${ }^{6-8}$. It is believed that the germicidal property of metals, especially heavy metals, is due to oligodynamic effect in which the metal and metal compounds, when introduced into the interior of bacterial cells, have the ability to change and then kill them in a specific way. Copper and silver are the most studied metals for oligodynamic action ${ }^{9}$. The data from silver suggest that its ions denature the proteins in the bacterial cells by binding to the reactive groups, resulting in their inactivation ${ }^{10}$.

Different factors influence the efficiency of silverand copper-based compounds, such as the particle size and particle size distribution. In these cases, a reduction of the particle size of silver and copper nanoparticles is a reliable solution to improve their efficiency and biocompatibility. In this field, nanotechnology has a direct effect on the elimination of particle size limitations and changing the world outlook regarding science ${ }^{10,11}$.

In this study we investigated the stabilization of nano silver on polyester filament yarn in order to produce a machine-made carpet with permanent antibacterial characteristics. 


\section{MATERIALS}

A nano-silver colloid was obtained from US Research Nano Material Company. The polyester filament yarns as a pile, warp and weft in a machine-made carpet were provided by the Farrokh Sepehr Kashan Textie Company. Gluteraldehyde (cross linking agent) and $\alpha$-amino propyl tri-etoxy silane were provided by the Sigma-Aldrich Company on a laboratory scale. An amphoteric surfactant based on amino betaine was provided by the Carp Company.

\section{METHODS}

Nano-silver colloids, including a cross-linking agent and amphoteric surfactant in different concentrations, were applied to the polyester filament yarn and the back of a machine-made carpet using a spraying method. The nano-silver-coated polyester filament yarn and polyester machine-made carpet were dried and cured in the stenter at $130{ }^{\circ} \mathrm{C}$ for $6 \mathrm{~min}$.

\section{ANALYSIS}

To predict the stability of the anti-bacterial characteristics, the nano-silver back-coated polyester machinemade carpets were analysed according to ATCC 27853, 25923 and 25922 some $72 \mathrm{~h}$ before and after a washing process in the Pasteur Institute of Iran.

The anti-bacterial characteristic of the nano-silvercoated machine-made carpet were measured based on the growth of different bacteria, such as E. coli, P. aeruginosa and $S$. aureus with respect to the reference sample.

The stability of the nano-silver colloids and their particle size distribution were analysed using the DLS (dynamic light scattering) method at $25^{\circ} \mathrm{C}$ (Malvern seri nano (zeta sizer) model DLS).
The FTIR analysis of the obtained solution from washing the nano-silver-coated polyester filament was carried out using Fourier-transform spectroscopy in the range $300 \mathrm{~cm}^{-1}$ to $4000 \mathrm{~cm}^{-1}$.

The distribution of nano-silver on the back of the polyester-filament machine-made carpet was analysed using the FESEM method in $1.89 \mathrm{KX}$ (Philips model FESEM).

\section{PREPARATION METHOD}

The Mac Farlan solutions of different bacteria such as $P$. aeruginosa (ATCC 27853), S. aureus (ATCC 25923) and E. coli (ATCC 25922) at a concentration of $1.5 \times 10^{8} \mathrm{CFU} / \mathrm{mL}$ were prepared in the first stage.

During the next stage, the nano-silver-coated machine-made carpet and the reference machine-made carpet were put in contact with the Mac Farlen solution of different bacteria for $24 \mathrm{~h}$. After the cultivation and incubation process for $72 \mathrm{~h}$ at $37{ }^{\circ} \mathrm{C}$, the growth of the bacteria were analysed.

\section{RESULTS AND DISCUSSION}

\subsection{Particle size distribution of nano-silver colloid}

The particle size distribution of the nano-silver colloid was measured using the DLS method. The results showed that the average size of the nano-silver colloid and the Pdi constant were about $49.08 \mathrm{~nm}$ and $0.408 \mathrm{~nm}$, respectively. Figure 1 shows the size distribution of the nano-silver.

\subsection{Stability of the nano-silver colloid}

The stability of the nano-silver colloid was measured using the DLS method according to the zeta-potential value. The results showed that the nano-silver colloid has

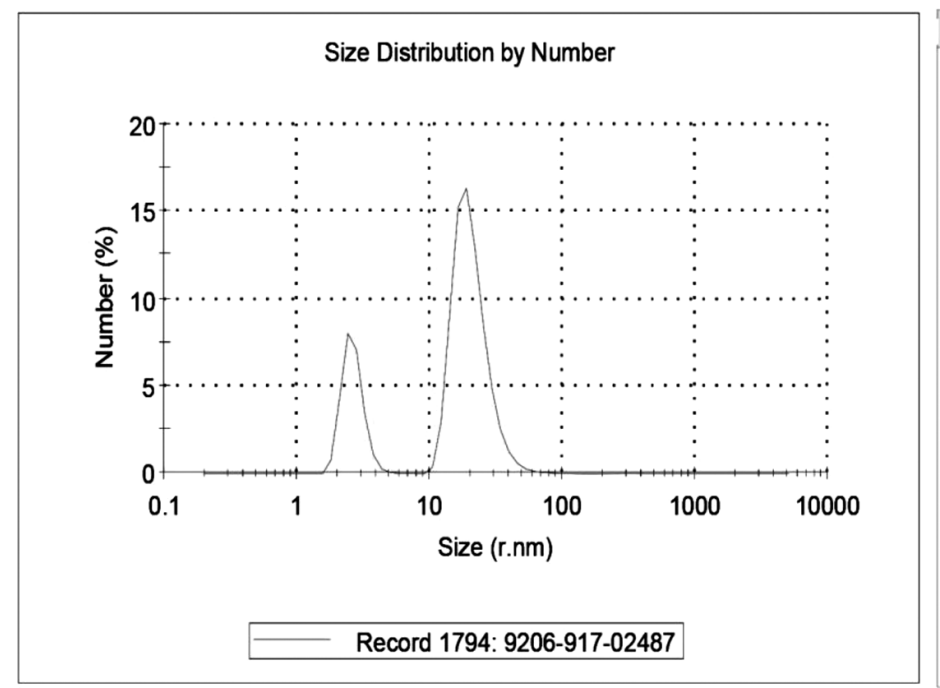

\begin{tabular}{|c|c|c|c|}
\hline $\begin{array}{l}\text { Size } \\
\text { r.nm }\end{array}$ & $\begin{array}{c}\text { Number } \\
\%\end{array}$ & $\begin{array}{l}\text { Size } \\
\text { r.nm }\end{array}$ & $\underset{\%}{\text { Number }}$ \\
\hline 0.2000 & & & \\
\hline 0.2316 & 0.0 & 39.41 & 1.3 \\
\hline 0.2682 & o.o & $\begin{array}{l}45.64 \\
52.85\end{array}$ & 0.6 \\
\hline $\begin{array}{l}0.3106 \\
0.3597\end{array}$ & $\begin{array}{l}0.0 \\
0.0\end{array}$ & $\begin{array}{l}52.85 \\
61.21\end{array}$ & $\begin{array}{l}0.3 \\
0.1\end{array}$ \\
\hline 0.4166 & 0.0 & 70.89 & 0.1 \\
\hline 0.4825 & 0.0 & 82.09 & 0.0 \\
\hline 0.5587 & 0.0 & 95.07 & 0.0 \\
\hline 0.6470 & 0.0 & 110.1 & 0.0 \\
\hline 0.7493 & o. o & 127.5 & o. o \\
\hline 0.8678 & 0.0 & 147.7 & 0.0 \\
\hline 1.005 & o.o & & 0.0 \\
\hline 1.164 & o.o & 198.0 & o. 0 \\
\hline 1.348 & 0.0 & 229.3 & 0.0 \\
\hline $\begin{array}{l}1.561 \\
1\end{array}$ & 0.0 & 265.6 & 0.0 \\
\hline $\begin{array}{l}1.808 \\
2.093\end{array}$ & 0.8 & $\begin{array}{l}307.6 \\
356\end{array}$ & 0.0 \\
\hline $\begin{array}{l}2.093 \\
2.424\end{array}$ & $\begin{array}{l}4.2 \\
8.0\end{array}$ & $\begin{array}{l}356.2 \\
412.5\end{array}$ & $\begin{array}{l}0.0 \\
0.0\end{array}$ \\
\hline 2.807 & 7.1 & 477.7 & 0.0 \\
\hline 3.251 & 3.4 & 553.2 & 0.0 \\
\hline 3.765 & 1.1 & 640.7 & 0.0 \\
\hline 4.360 & 0.3 & 741.9 & 0.0 \\
\hline 5.050 & 0.1 & 859.2 & 0.0 \\
\hline 5.848 & 0.0 & 995.1 & 0.0 \\
\hline 6.772 & o. 0 & 1152 & 0.0 \\
\hline 7.843 & 0.0 & 1335 & 0.0 \\
\hline $\begin{array}{r}9.083 \\
10.52\end{array}$ & O.o & 1545 & o. \\
\hline $\begin{array}{l}10.52 \\
12.18\end{array}$ & $\begin{array}{l}0.4 \\
2.9\end{array}$ & $\begin{array}{l}1790 \\
2073\end{array}$ & $\begin{array}{l}0.0 \\
0.0\end{array}$ \\
\hline 14.11 & 9.1 & 2400 & 0.0 \\
\hline 16.34 & 15.2 & 2780 & 0.0 \\
\hline 18.92 & 16.3 & 3219 & 0.0 \\
\hline 21.91 & 12.9 & 3728 & 0.0 \\
\hline 25.37 & 8.4 & 4317 & 0.0 \\
\hline 29.39 & 4.8 & 5000 & 0.0 \\
\hline
\end{tabular}

Figure 1: Size distribution of nano silver colloid

Slika 1: Razporeditev velikosti nanodelcev srebra v koloidu 


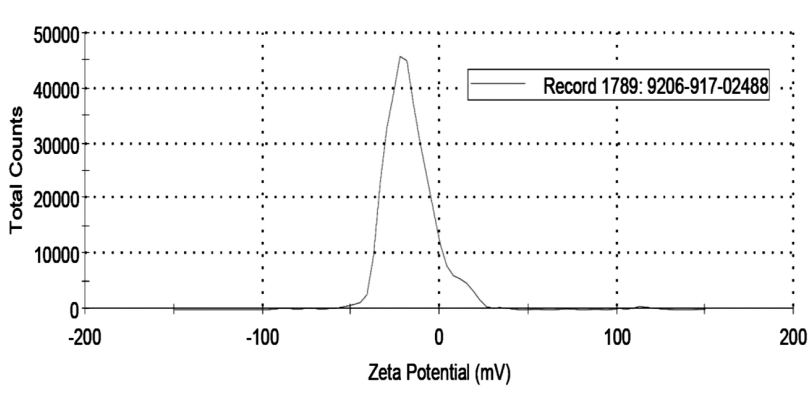

Figure 2: Zeta-potential distribution of nano-silver colloid Slika 2: Zeta potencial razporeditve nanodelcev srebra v koloidu

a suitable stability under normal conditions. In Figure 2, the zeta-potential distribution of the nano-silver is shown. According to Figure 2, the zeta-potential for a nano-silver colloid is about $-17.2 \mathrm{MV}$. In addition, the nano-silver particle colloid has a suitable stability against sedimentation.

\subsection{Distribution of nano-silver on the back of polyester machine-made carpet}

The distribution of the nano silver on the back of the machine-made carpet is shown in a FESEM micrograph in 1.89 KX. According to Figure 3, it can be concluded that the anti-bacterial characteristics of the polyester-filament machine-made carpet is due to the nano-silver material that was applied on the polyester filament yarn and the back of the machine-made carpet.

\subsection{Anti-bacterial test}

The nano-silver back-coated machine-made carpets before and after washing were tested according to ATCC 27853, 25923 and 25922 in 72 h. In Tables 1 and 2, the
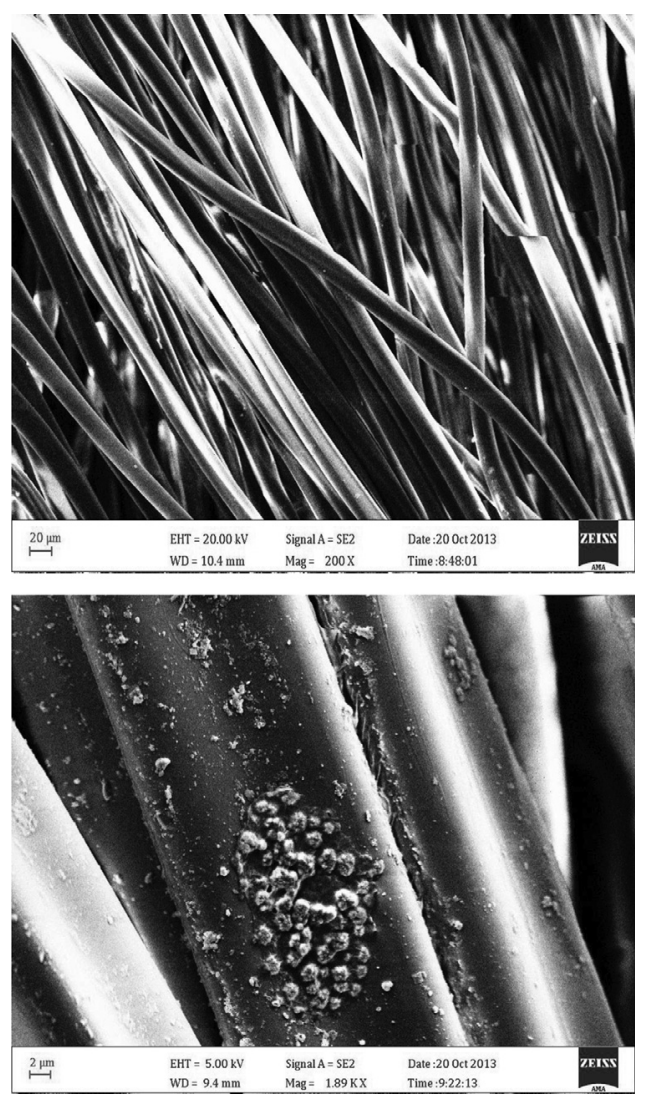

Figure 3: SEM micrographs of samples: a) polyester-filament yarn, b) nano-silver-coated polyester-filament yarn

Slika 3: SEM-posnetka vzorcev: a) vlakna poliestrske preje, b) z nanodelci srebra prekrita vlakna poliestrske preje

concentration of bacteria before and after the washing processes are presented.

The results showed that the nano-silver-coated polyester-filament machine-made carpet before and after

Table 1: Anti-bacterial characteristics of samples before washing Tabela 1: Protibakterijske lastnosti vzorcev pred pranjem

\begin{tabular}{|c|c|c|c|}
\hline Name of test bacteria & $\begin{array}{l}\text { Bacteria concentration } \\
(\mathrm{CFU} / \mathrm{mL})\end{array}$ & \multicolumn{2}{|c|}{ The growth of bacteria after $72 \mathrm{~h}(\mathrm{CFU} / \mathrm{mL})$} \\
\hline \multirow{2}{*}{ E. coli (ATCC 25922) } & \multirow{2}{*}{$1.5 \times 10^{8}$} & Sample control & $1.5 \times 10^{6}$ \\
\hline & & Anti bacterial sample & $8.5 \times 10$ \\
\hline \multirow{2}{*}{ P. aeruginosa (ATCC 27853) } & \multirow{2}{*}{$1.5 \times 10^{8}$} & Sample control & $1.5 \times 10^{6}$ \\
\hline & & Anti bacterial sample & $7.5 \times 10$ \\
\hline \multirow{2}{*}{ S. aureus (ATCC 25923) } & \multirow{2}{*}{$1.5 \times 10^{8}$} & Sample control & $1.5 \times 10^{6}$ \\
\hline & & Anti bacterial sample & $7.5 \times 10$ \\
\hline
\end{tabular}

Table 2: Anti-bacterial characteristics of samples after washing

Tabela 2: Protibakterijske lastnosti vzorcev po pranju

\begin{tabular}{|c|l|l|c|}
\hline Name of test bacteria & $\begin{array}{c}\text { Bacteria concentration } \\
(\mathrm{CFU} / \mathrm{mL})\end{array}$ & \multicolumn{2}{|c|}{ The growth of bacteria after 72 h $(\mathrm{CFU} / \mathrm{mL})$} \\
\hline \multirow{2}{*}{. coli (ATCC 25922) } & $1.5 \times 10^{8}$ & Sample control & $8.5 \times 10^{6}$ \\
\cline { 2 - 4 } & Anti bacterial sample & $1.5 \times 10^{6}$ \\
\hline P. aeruginosa (ATCC 27853) & $1.5 \times 10^{8}$ & Sample control & $7.5 \times 10$ \\
\cline { 2 - 4 } S. aureus (ATCC 25923) & $1.5 \times 10^{8}$ & Anti bacterial sample & $1.5 \times 10^{6}$ \\
\hline
\end{tabular}



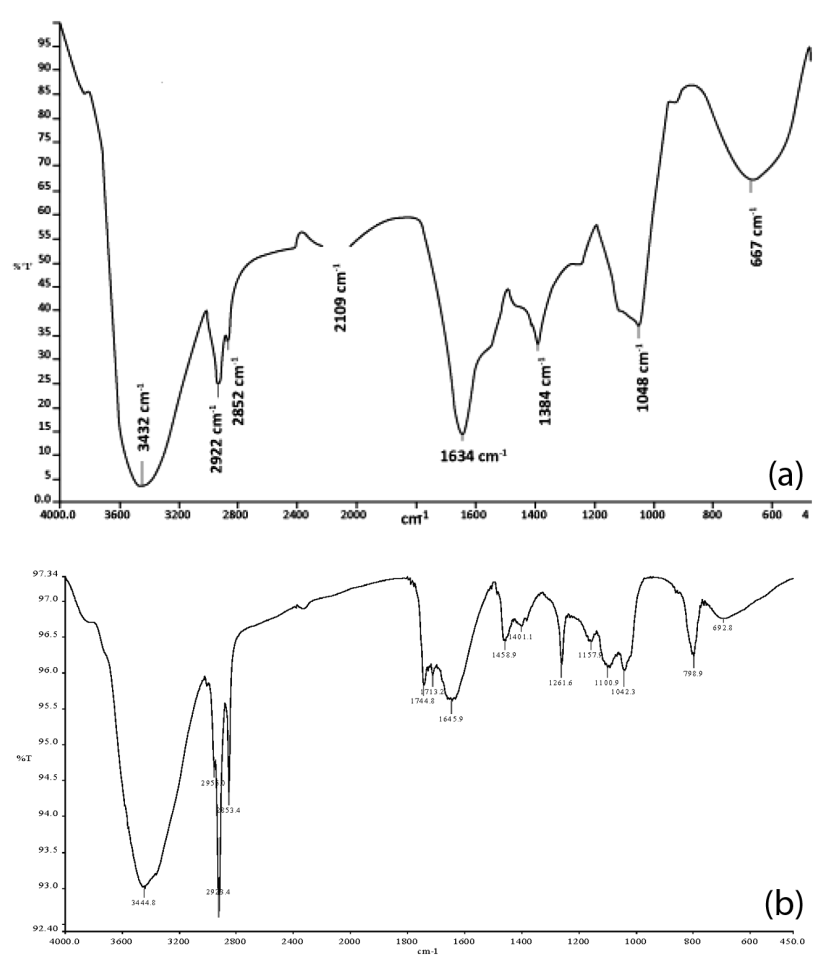

Figure 4: FTIR analysis a) nano silver b) solution from washing Slika 4: FTIR-analiza, a) nanodelci srebra, b) raztopina pri pranju

washing has suitable anti-bacterial characteristics against E. coli, $P$. aeruginosa and S. aureus $(99.9 \%$ anti-bacterial characteristic).

\subsection{FTIR analysis of nano-silver-coated polyester-fila- ment machine-made carpet}

In order to demonstrate the permanence of the anti-bacterial characteristic in a polyester-filament machine-made carpet, FTIR analyses carried out on a nano-silver colloid and the obtained solution from washing the nano-silver-coated polyester-filament machinemade carpet. Figure 3 shows the FTIR analysis of the nano-silver colloid and the obtained solution from washing the nano-silver-coated polyester-filament machinemade carpet (Figure 4).

According to Figure 4a, the sharp peaks at $1634 \mathrm{~cm}^{-1}$ and $1384 \mathrm{~cm}^{-1}$ indicate the formation of asymmetric and symmetric stretching modes of metal carbonyl groups. This is due to the stabilization of the silver nano particles by the -COO- group of amino betaine (as an amphoteric surfactant). The peaks at $3432 \mathrm{~cm}^{-1}$ and $2922 \mathrm{~cm}^{-1}$ are related to the $\mathrm{C}-\mathrm{H}$ stretching bond of the propyl and the amine groups of the $\alpha$-amino propyl tri-etoxy silane ${ }^{12}$.

According to Figure 4b, the sharp peaks at 3444 $\mathrm{cm}^{-1}$ and $2934 \mathrm{~cm}^{-1}$ are related to the $\mathrm{O}-\mathrm{H}$ and $\mathrm{C}-\mathrm{H}$ groups of the soap solution, which are used for washing the nano-silver-coated polyester-filament machine-made carpet.

Moreover, the lack of any peak at $1634 \mathrm{~cm}^{-1}$ and $1384 \mathrm{~cm}^{-1}$ indicates that the washing process had no effect on removing the silver nanoparticles from the anti-bacterial polyester-filament machine-made carpet.

\section{CONCLUSION}

The results showed that the nano-silver-coated polyester-filament machine-made carpet has a permanent anti-bacterial characteristic. This is due to the modification process carried out on the nano-silver before applying it to polyester-filament yarn and the back of the machine-made carpet. Having permanent anti-bacterial characteristics in the machine-made carpet make it more suitable for use in crowded places by removing the bad smells in a machine-made carpet due to the direct contact of people with machine-made carpet's surface.

\section{Acknowledgement}

This work was done in the Farrokh Sepehr Kashan Company. Mr. Ali Farrahi and Mr. Ahmad Farrahi are grateful for the financial support.

\section{REFERENCES}

${ }^{1}$ S. A. Jones, P. G. Bowler, M. Walker, D. Parsons, Wound Repair and Regeneration, 12 (2004) 3, 288-294, doi:10.1111/j.1067-1927. 2004.012304.x

${ }^{2}$ S. Silver, L. T. Phung, Annu. Rev. Microbiol., 50 (1996), 753-789, doi:10.1146/annurev.micro.50.1.753

${ }^{3}$ M. Catauro, M. G. Raucci, F. De Gaetano, A. Marotta, J. Mater. Sci. Mater. Med., 15 (2004) 7, 831-837, doi:10.1023/B:JMSM. 0000032825.51052 .00

${ }^{4}$ J. H. Crabtree, R. J. Burchette, R. A. Siddiqi, I. T. Huen, L. L. Hadnott, A. Fishman, Perit. Dial. Int., 23 (2003) 4, 368-374

${ }^{5}$ G. Zhao, S. E. Stevens Jr., Biometals, 11 (1998) 1, 27-32, doi:10.1023/A:1009253223055

${ }^{6}$ C. E. Santo, N. Taudte, D. H. Nies, G. Grass, Appl. Environ. Microbiol., 74 (2008) 4, 977-986, doi:10.1128/AEM.01938-07

${ }^{7}$ S. A. Wilks, H. Michels, C. W. Keevil, International Journal of Food Microbiology, 105 (2005) 3, 445-454, doi:10.1016/j.ijfoodmicro. 2005.04.021

${ }^{8}$ D. S. Blanc, P. Carrara, G. Zanetti, P. Francioli, J. Hosp. Infect., 60 (2005) 1, 69-72, doi:10.1016/j.jhin.2004.10.016

${ }^{9}$ A. J. Varkey, Scientific Research and Essays, 5 (2010) 24, 3834-3839

${ }^{10}$ M. Yamanaka, K. Hara, J. Kudo, Appl. Environ. Microbiol., 71 (2005) 11, 7589-7593, doi:10.1128/AEM.71.11.7589-7593.2005

${ }^{11}$ J. S. Kim, E. Kuk, K. N. Yu, J. H. Kim, S. J. Park, H. J. Lee, S. H. Kim, Y. K. Park, Y. H. Park, C. Y. Hwang, Y. K. Kim, Y. S. Lee, D. H. Jeong, M. H. Cho, Nanomedicine: Nanotechnology, Biology, and Medicine, 3 (2007) 1, 95-101, doi:10.1016/j.nano.2006.12.001

${ }^{12}$ R. Augustine, K. Rajarathinam, Int. J. Nano Dim., 2 (2012) 3, 205-212 